\title{
RELATÍV VÁGóMOZGÁSOKKAL GENERÁLT PONTFELHŐK SZÚRÉSI NEHÉZSÉGEI
}

\section{DIFFICULTIES OF PROCESSING POINTS CLOUD GENERATED BY RELATIVE CUTTING MOVEMENTS}

\author{
Tolvaly-Roșca Ferenc ${ }^{1}$, Forgó Zoltán ${ }^{2}$ \\ ${ }^{1}$ Sapientia EMTE, Müszaki és Humán Tudományok Kar Marosvásárhely, Gépész- \\ mérnöki Tanszék, Cím: 540485, Románia, Segegesvári út, 1C, Telefon / Fax: +40 \\ 265206 210/+40265206211, levelezésicím, tferi@ms.sapientia.ro \\ ${ }^{2}$ Sapientia EMTE, Müszaki és Humán Tudományok Kar Marosvásárhely, Gépész- \\ mérnöki Tanszék, Cím: 540485, Románia, Segegesvári út, 1C, Telefon / Fax: +40 \\ 265206 210/+40265206211, levelezési cim,zforgo@ms.sapientia.ro
}

\begin{abstract}
The Mixed Gear Modeling Method, developed by the authors, requires manipulation of large Points Clouds, situated in a spatial volume. Regular Points Cloud software's and manipulation techniques deals with points situated on surfaces, points obtained with scanning techniques. Generating points Clouds as in the developed methods cannot be manipulated with this usual techniques, therefore it is necessary to develop new techniques: filtering algorithm. The difficulties to develop a new approach consist in the spatial placement of the points, in the particular shape of the Clouds. As the generated points are partially concave and partially convex the usual software tools are not working properly with this kind of Points Clouds, raising some particular issues. The present paper shows some results from the earlier stage of the development, showing the difficulties raised during the application of different Points Cloud filtering algorithms.
\end{abstract}

Keywords: Points Cloud, relative cutting movements, filtering algorithm

\section{Összefoglalás}

A szerzők által kidolgozott vegyes fogaskerék generáló módszer egy térfogatban és nem felületeken elhelyezkedő terjedelmes pontfelhők kezelését igényli. Az ismert pontfelhőkezelő szoftverek és eljárások felületeken található pontokat kezelnek, amelyeket általában 3D szkennelési technikákkal kapunk meg. A relatív generáló mozgásokkal generált pontfelhők esetében nem alkalmazhatók a hagyományos eljárások, ezért egy új szürőalgoritmust kellett kidolgozni. Az új pontfelhőkezelő eljárásnál nehézséget jelent a pontok térfogatban és nem felületen való elhelyezése és ezeknek sajátságos formája. Mivel az így kapott pontfelhők jellemző alakja konvex és konkáv is egyszerre, az ismert eljárások nem működnek megfelelően, amint első kísérleteink során azonnal meg is tapasztaltunk. A jelen dolgozat e nehézségeket igyekszik szemléltetni, a fejlesztés első szakaszaiban kipróbált szürőalgoritmusokra épülő eredmények elemzésével.

Kulcsszavak: pontfelhö, relativ generáló mozgások, szüröalgoritmus 


\section{Bevezető}

A forgácsolással gyártott alkatrészek, így a fogaskerekek is szinte kizárólag először számítógépes modellezéssel készülnek el. A számítógépes modellek megfelelő pontosságúak kell legyenek, az előállított fogaskerekek felülete gyorsan, illetve kielégítő pontossággal kell legyen megépítve. Ha CAD környezetben modellezzünk, matematikai egyenletek alapján, akkor a felületeket tetszőleges pontossággal építhetjük meg, azonban lehetetlen az analitikus egyenletekkel nem rendelkezö felületek, mint például fogaskerék-fogazatok valós láb- és fejfelületeinek az előállítása. A nem matematikai egyenleteken alapuló felületgenerálási módszerek között ismert az előgyártmányból való folytonos szerszámkivonás, az úgynevezett „,merevtest kivonásos módszer”. Ezt viszonylag jól lehet alkalmazni a legkülönbözőbb alkatrészek modellezésre, de igen nagy számítógépteljesítményt igényel.

Egy ehhez hasonló modellezési eljárást javasoltunk [1] ,,vegyes CAD eljárás” megnevezéssel. A megnevezés a merevtestkivonás módszerének relatív mozgásait és az utólagos CAD modellezési eljárások ötvözését igyekszik lefedni. A módszer elönye, hogy nem igényel matematikai egyenleteket, és jól alkalmazható (a megfelelő pontosság elérése után) ismételt és nagyszámú módosítások szinte azonnali modellezésére.

A javasolt eljárás a fogazat vagy tetszöleges felület generálásának a relatív mozgásait valósítja meg virtuális környezetben egy generálási modell felállításával. Az eljárás során a vágóéleken rögzített pontok koordinátáit a generáló mozgás minden egyes lépésében egy rögzített koordinátarendszerhez képest adunk meg, ezeket tároljuk, majd az így kapott pontfelhőt (Points Cloud) matematikai szürőkkel dolgozzuk fel.
Megjegyezendő, hogy hasonló cél elérése érdekében más szerzők is publikáltak a vegyes CAD eljárástól eltérő eljárásokat, amelyek a fogfelületek burkolóját igyekeznek meghatározni [2].

Jelen dolgozat szerzői azonban egy teljes CAD eljárásokon alapuló eljárást igyekeztek kidolgozni. Ennek érdekében a generált pontokra építve, a pontfelhő szürése után fennmaradt pontokra Bezier Spline felületeket, majd ezekkel merev testmodelleket építünk. Amint bebizonyosodott [3], a kidolgozott módszer igen gyors és rendkívül rugalmas.

\section{A generált pontfelhő}

$\mathrm{Az}$ 1. ábrán látható pontfelhők egy konvolut csigamaró segítségével megvalósított ferde fogazat generálásának eredménye. A generálás adatai a következők:

Kerék: $\mathrm{z}=25, \mathrm{~m}=5 \mathrm{~mm}, \mathrm{x}=0$

Csigamaró: $\mathrm{z}=9, \mathrm{dm}=77.5 \mathrm{~mm}, \gamma=$ $3^{\circ} 45^{\prime} 6^{\prime \prime}$, generálás szöglépése $=5^{\circ}$, generálási szög $=18^{\circ}$.

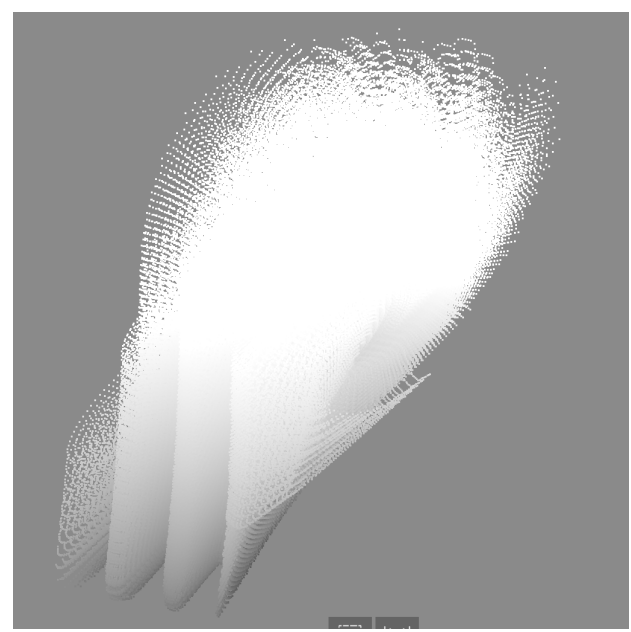

1. ábra. A generált pontfelhö Autodesk ReCap környezetben

Amint azonnal megfigyelhető, a generált pontok a generálóélen meghatározott pontok halmazát alkotják, a generálás fo- 
lyamán felvett szerszám-előgyártmány relatív helyzeteknek megfelelően. Az ábrán látható pontok egy része gyakorlatilag a fogaskerék fogárkaiban találhatók, egy részük a fogak felületén, illetve fennmaradt részük a fogaskeréken kívüli térben. Egyértelmüen a pontfelhő azon pontjaira van szükségünk, amelyek a fogaskerék szélességén (magasságán) belül a fogak oldalain vannak. Ezek gyakorlatilag a pontfelhő burkolóján helyezkednek el. Az így kapott pontfelhő sajátos pontfelhő: nem egy felületen vagy felületseregen fekvő pontok halmaza, mint a 3D letapogatással kapott pontfelhők esetén. Ha az utóbbi lenne, nagyon sok alkalmazásban lévő szoftverrel lehetne felületet építeni rájuk, illetve viszonylag egyszerü lenne a testmodell előállítása.

A saját eljárással generált pontok egy térfogatban foglalnak helyet, ismeretlen sürüségi elosztással, illetve egyértelmüen ismeretlen burkolóval. Egy ilyen ponthalmaz fogaskerekek estében, általában vegyes konkáv és konvex burkoló felületekkel rendelkezik. Ezen ponthalmaz kezelése és szürése egyedi megoldást igényel.

\section{Pontfelhő szűrőalgoritmusok}

Első megközelítésünk a pontfelhő fogaskerék szélességére való korlátozására irányult. A 2. ábra a méretekre szürt pontfelhőt ábrázolja. Ezen már jól azonosítható a feladat bonyolultsága. Jól látható a pontok térbeni elhelyezése és a várható burkolófelületek bonyolultsága.

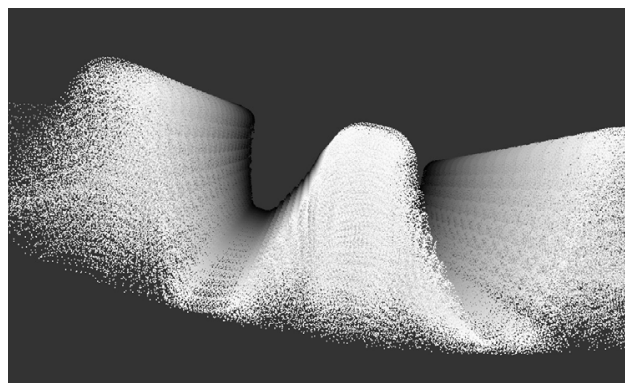

2.ábra. Pontfelhö tengelyirányú nézetböl
A feladat további lépéseiben a 2. ábrán látható pontfelhő szürésére alkalmas kész algoritmust próbáltunk keresni.

Ezek a lépések a Konvex Hull [4, 5] és Qhull (Látható pont algoritmus) [6] algoritmusokhoz vezetett. Habár az első információk síkbeli lehetőségekről számoltak be $[4,5,6]$, ezek az algoritmusok Meshlab ingyenes szoftverben is megtalálhatók 3 dimenziós pontfelhők kezelésére is.

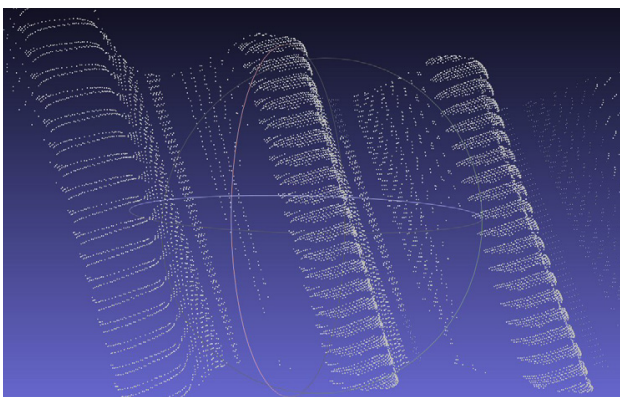

3. ábra. Konvex Hull szüröalgoritmus eredménye
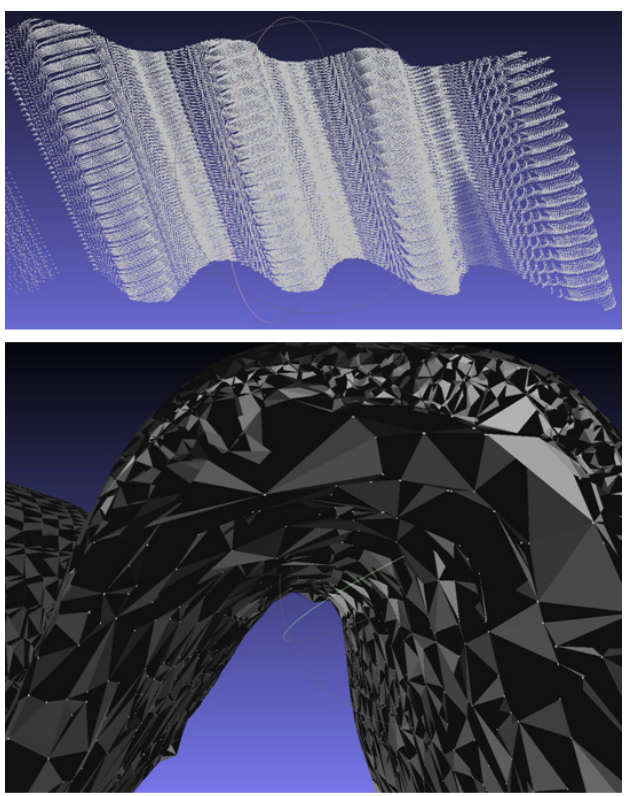

4. ábra. Qhull szüröalgoritmus eredménye

Amint a 3. ábrán megfigyelhető, a Konvex Hull algoritmus egyértelmüen 
használhatatlannak bizonyul, mivel a burkoló-felületen található pontok csekély számban maradnak meg.

A 4. ábrán a Visible Point szürőalgoritmus eredménye látható (felül).

A 4. ábra alsó képén látható, hogy habár első ránézésre úgy tünik, a Qhull szürőalgoritmus helyes eredményt mutatna, a pontok lényegében nagy vastagságban egy térfogatban és nem a burkolófelületen vannak. A szürő paramétereit változtatva azonnal láthatóvá válik, hogy vékonyítva a ponthalmazt a burkolófelületen található pontok legnagyobb részét megint elveszítjük.

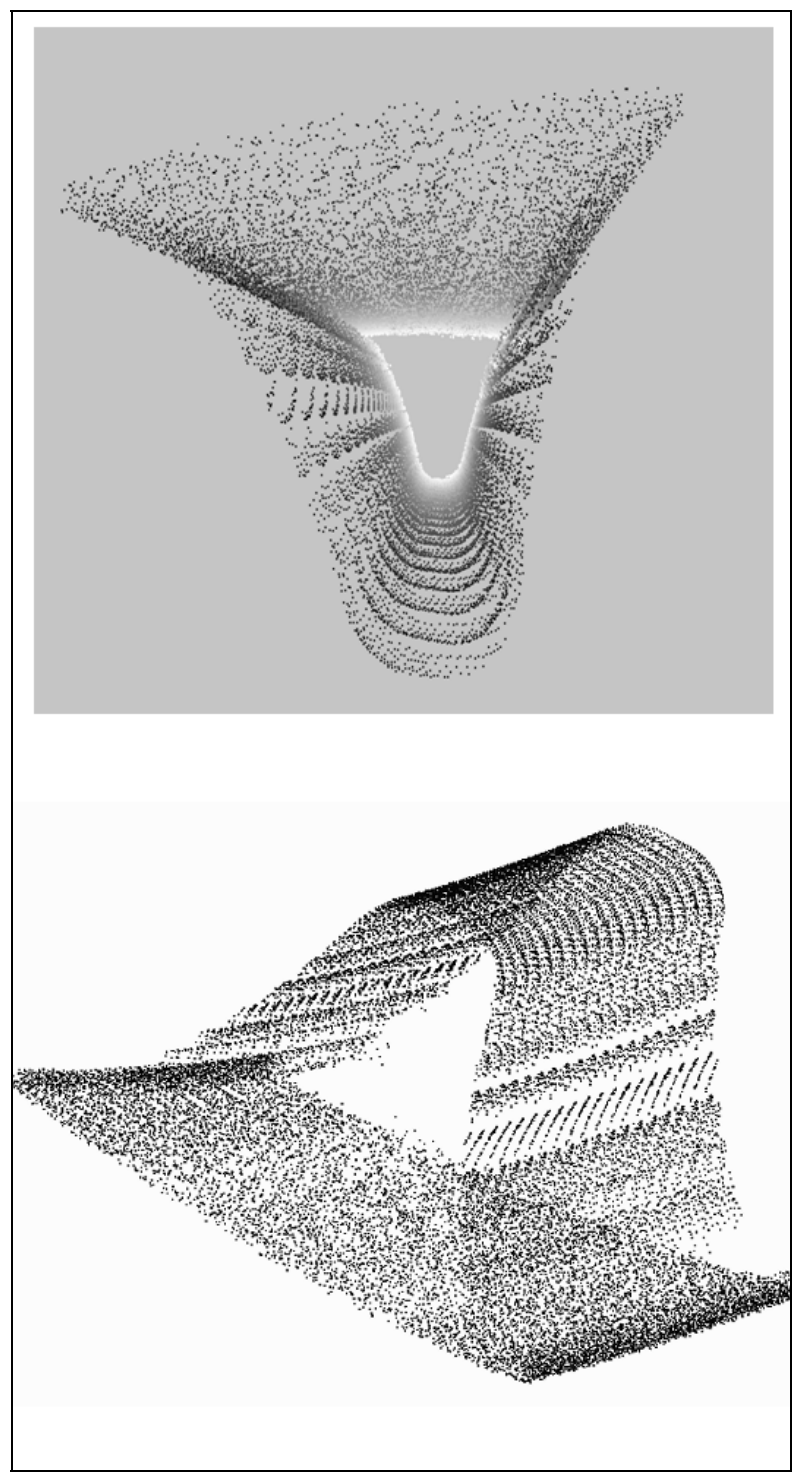

5. ábra. Saját algoritmussal való szürt pontok halmaza egy fogárok esetében 
A helyes megoldást az alpha-shape algoritmus [7] eredményezi. Mivel ez az algoritmus síkban müködik megfelelően, saját programot írtunk, amely síkmetszetekben alkalmazza az alpha-shape algoritmust. Mivel a saját algoritmus bemutatása nem célunk a jelen dolgozatban, csak alkalmazásának eredményére szorítkozunk, amelyet az 5. ábrán szemléltetünk.

$\mathrm{Az}$ algoritmus paramétereinek beállításával alapvetően meghatározható a generált pontfelhő szürési eredménye. Ezek változtatása kizárólag kísérleti úton történt meg. Az algoritmus egyik fö paramétere alapvetően módosítja a burkolófelület meghatározását. A kísérleti úton meghatározott legmegfelelőbb értékek alapján a 6. ábrán látható eredményeket kaptuk. Az ábra a szürt pontokra felépített fogaskerék testmodelljét szemlélteti, felméréseink alapján hasonlító pontossággal az elméleti egyenletekre épülő modellel, illetve a merevtest kivonásos módszerével generált modellhez, sokkal rövidebb generálási idővel.

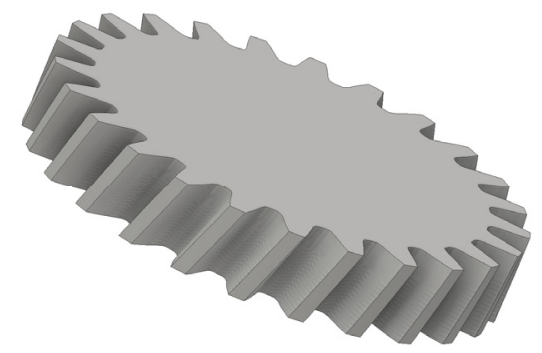

\section{6. ábra. A szürt pontokra felépitett testmodell}

Felméréseink alapján a generálási, szürési és modellfelépítési összidő csupán töredéke a merevtest generálási módszerének, pontossága tetszőlegesen növelhető, és ez nem vonja maga után a generálási idő exponenciális növekedését.

\section{További fejlesztési lépések}

A kidolgozott eljárás folyamatos fejlesztés alatt áll. A szürőalgoritmus paraméterei- nek további tesztelése szükséges, a minimális generálási idő és maximális pontosság elérése érdekében. Ezt csak nagyszámú kísérleti futtatás és minden esetben az elért pontosság értékelése teszi lehetővé. A szürőalgoritmus egyelőre Matlab környezetben fut, a generálóprogram eredményét egy szöveges állományba mentjük, majd a Matlab programba importáljuk. Ez egy eléggé időigényes és nehézkes eljárás, le kell majd a programot kompilálni és egy .dll állomány formájában a generáló környezethez csatolni.

A generálóélek által meghatározott kezdeti ponthalmaz sürüsége az élgeometria konfigurációja alapján van meghatározva. Az egyenes szakaszokon kevésbé sürü, illetve az ívelt szakaszokon sürübb. Nagyszámú kísérlet eredményeként rájöttünk, hogy ez nem elégséges kritérium: a generálópontok sürüségének meghatározásánál figyelembe kell venni a vágóéleken található pontok távolságát a szerszám forgástengelyéhez képest. Kisseb távolságra levő élszakaszok esetén kisseb sürüség is megengedett, a nagyobb távolságra levőknél pedig nagyobb sürüség szükséges a geometriai alakzatra jellemző pontelosztás mellett.

\section{Következtetések}

- A létező szakirodalomban nem találtunk olyan algoritmust, amely egyszerüen megoldaná a pontfelhőszürési feladatot a fogazatoknál jelentkező vegyes konkáv és konvex ponthalmazok esetében.

- Sík ponthalmazok esetében a konvex és konkáv sík ponthalmazok jól kezelhetők alpha-shape algoritmussal [7].

- Az alpha-shape szürőalgoritmus beépítése a saját fogárokponthalmaz szürőalgoritmusunkba kiváló eredményeket mutat.

- A kidolgozott pontgeneráló és pontszürő eljárás sajátságosan fogazatok univerzális és gyors generálására alkalmas. 


\section{Köszönetnyilvánítás}

A kutatási tevékenységet a Sapientia Erdélyi Magyar Tudományegyetem Kutatási Programok Intézete támogatta a 12/19/2015.04.08. számú szerződés alapján, az Egyetemi Kutatási Program **2015/2016 ** keretén belül.

\section{Szakirodalmi hivatkozások}

[1] Tolvaly-Roșca, F., Forgó, Z.: Mixed CAD Method to Develop Gear Surfaces Using the Relative Cutting Movements and NURBS Surfaces, Elsevier, Procedia Technology 19, 2015, pp. 20-27, http://dx.doi.org/10.1016/j.protcy.2015.02.04

[2] Bendefy, A. G., Horák, P.: Gear Pair Generation With the Method of Transposed Lines of Action. DS 84: Proceedings of the DESIGN 2016 14th International Design Conference, pp. 129-136.

[3] Tolvaly-Roșca, F., Forgó Z.: Mixed CAD Method to Develop Gear Surfaces Using the
Relative Cutting Movements and NURBS Surfaces. Elsevier, Procedia Technology 19, 2015, pp.20-27, http://dx.doi.org/10.1016/j.protcy.2015.02.04

[4] Edelsbrunner, H., Kirkpatrick D., David G.; Seidel, R.: On the shape of a set of points in the plane. IEEE Transactions on Information Theory 29 (4), 1983, pp. 551-559, doi:10.1109/TIT.1983.1056714

[5] Andrew, A. M. (1979): Another efficient algorithm for convex hulls in two dimensions. Information Processing Letters 9 (5), pp. 216-219, doi:10.1016/0020-0190(79)90072-3.

[6] http://www.qhull.org/

[7] Kreveld, M., Lankveld, T., Veltkamp, R.: On the shape of a set of points and lines in the plane. Technical Report UU-CS-2011-017 June 2011, Department of Information and Computing Sciences Utrecht University, Utrecht, The Netherlands, 2011, ISSN: 09243275, pp.1-24. 